\title{
THE SASKATCHEWAN NATURAL HISTORY SOCIETY
}

BOARD OF DIRECTORS (October 1971, to October, 1972)

SLATE OF OFFICERS:

Honorary President.

President

Past President

First Vice-President

Second Vice-President.

Treasurer

Corresponding Secretary ...

Recording Secretary

\section{REPRESENTATIVES AT LARGE}

Harvey Beck, Calgary; Al Binnie, Regina; Richard Fyfe, Edmonton; Tom Gentles, Regina; Donald Hayward, Wolseley; Murdoch Nelson, Moose Jaw; Lloyd Peterson, Indian Head; Christine Pike, Waseca; Wayne Renaud, Saskatoon; Dr. Stanley Riome, Nipawin; Charles Shulver, Lafleche; Mrs. Sylvia van Brienen, Rosetown.

\section{PRESIDENTS OF LOCAL NATURAL HISTORY SOCIETIES}

Mrs. Mary Skinner, Indian Head; Mrs. D. Bromley, Maple Creek; Mrs. Leith Knight, Moose Jaw; Omar Aschim, Prince Albert; Gary Seib, Regina; Maureen Rever, Saskatoon; Dr. Jan Looman, Swift Current; William Popowich, Yorkton.

\section{APPOINTED DIRECTORS}

Blue Jay Editor, George F. Ledingham; Assistant Editors, Robert W. Nero, shop: Frank Brazier, 2657 Cameron Street, Regina; Circulation: Lorne Scott, Saskatchewan Museum of Natural History, Regina; Conservation: Thomas White 2580 Retallack Street, Regina; Editor of Newsletter: Muriel Galloway, 1549 Spadina Crescent E., Saskatoon; Publicity: Rose McLaughlin, Indian Head; Gordon Browne, 120 Acadia Drive, Saskatoon; Special Publications:: C. Stuart Houston, 863 University Drive, Saskatoon; Supervisor of Services: James Jowsey, 2635 Nineteenth Avenue, Regina.

\section{THE BLUE JAY}

Blue Jay Editor, George F. Ledingham; Assistant Editors, Robert W. Nero, Stan Rowe and Richard Fyfe.

All items for publication should be submitted to George F. Ledingham, Editor, 2335 Athol Street, Regina.

\section{SUBSCRIPTIONS - MEMBERSHIPS}

The classes of memberships in the SNHS are as follows: Regular, $\$ 3.00$; Supporting $\$ 5.00$; Sustaining $\$ 10.00$. Supporting and sustaining memberships include the regular membership fee plus a donation for which a receipt is available for income tax purposes, upon request. Bulk orders (minimum of five to one address) are available to junior club members and to educational institutions at the rate of $\$ 3.00$ for the first subscription and $\$ 1.00$ for each additional one.

Send all renewels and new memberships to THE TREASURER, SNHS, Box 1321, Regina, Saskatchewan. (Note: Bookshop orders and general inquiries should be sent to Box 1121).

\section{REPRINTS}

Requests for quantities of reprints of any article printed in the Blue Jay hould be sent to Printcraft, Ltd., Regina, Sask., within one month of publicaion. Contributors wishing a few extra copies of the current Blue Jay may get them at cost. Requests for these should be made to the Editor when material s submitted for publication. 